Nina Plešec

\title{
Sodelovanje šolske svetovalne službe s starši otrok s posebnimi potrebami
}

\begin{abstract}
Članek obravnava delo z otroki s posebnimi potrebami, ki so vključeni v redno osnovno šolo, in problem pomanjkanja strokovne podpore staršem v času postopka usmerjanja njihovih otrok. Opisuje vlogo šolske svetovalne službe in vlogo staršev v procesih sodelovanja in oblikovanja individualiziranega programa za otroka s posebnimi potrebami. Cilj raziskave, ki je potekala vokviru empiričnega dela diplomske naloge, je bil s pomočjo intervjujev pridobiti vidik socialnih delavk, ki delujejo v šolski svetovalni službi, in vidik staršev o celotnem postopku usmerjanja. Predvsem pa predstaviti izkušnjestarševna potido pridobitvedodatnestrokovne pomočiza otroka. Rezultati, pridobljenizintervjujissocialnimidelavkami, kažejo, dasocialnedelavke pristarših opažajo predsodke in strah pred etiketiranjem otroka ob postopku usmerjanja. Starši pa menijo, da je potrebno večje sodelovanje šolske svetovalne službe s starši otrok s posebnimi potrebami. Ugotovitve raziskave kažejo, da bo v prihodnje treba večjo pozornost nameniti oblikovanju in izvajanju individualiziranih programov v osnovni šoli in strokovnemu delu s starši in otroki s posebnimi potrebami kot pa samemu postopku usmerjanja.
\end{abstract}

Ključne besede: socialno delo v šoli, individualiziran program, postopek usmerjanja, šolsko svetovanje, participacija otrok, participacija staršev.

Nina Plešec je univerzitetna diplomirana socialna delavka, in magistrica sociologije iz študijskega programa Sociologija - upravljanje organizacij, človeških virov in znanja. Kontakt: nina.plesec1@ gmail.com.

\section{Cooperation of school counselling service with parents of children with special needs}

The paper examines working with children with special needs in regular primary school and focuses on the problem of lack of professional support that parents receive during the procedure of determining their children's special educational needs. It describes the role of school counselling service and the role of parents in the processes of cooperation and the creation of an individualised programme for a child with special needs. The aim of the research, which was conducted for the empirical part of a BA thesis, was to obtain, through interviews, the perspective of social workers who are working in school counselling service and the aspect of parents about the whole procedure of determining special educational needs. But above all, to highlight the experience of parents on the way to obtaining additional professional assistance. Results obtained through interviews with social workers indicate that social workers have noticed that parents have some prejudices and fears related to labelling their child. Parents consider that greater cooperation with is needed with school counselling service. The findings of research show that in the future bigger attention should be given to the formation and the implementation of individualised programmes in primary schools and their professional work with parents and children with special needs, rather than to the procedure of determining their children's educational needs.

Key words: social work in school, individualised programme, placement procedure, school counselling, participation of children, participation of parents.

Nina Plešec is a university graduate social worker and a Master of Sociology - Management of Organizations, Human Resources and Knowledge. Contact: nina.plesec1@gmail.com.

\section{Uvod}

Ko starši ali šolski strokovni delavci opazijo pri otroku določene spremembe ali težave na učnem, vedenjskem, čustvenem ali drugem področju, se začne intenzivnejše delo z namenom raziskovanja, kakšne prilagoditve bi otroku pomagale, da bi se lažje spoprijemal z vsakdanjimi šolskimi izzivi. Če otrok potrebuje odločbo in z njo dodatne ure strokovne pomoči, to še zdaleč ni lahka pot za starše, če na 
tej poti ne dobijo vseh informacij, če niso seznanjeni s pravicami in možnostmi, če niso vključeni v postopke, kjer imajo kot starši pravico, in če od strokovnih delavcev ne dobijo ustrezne podpore.

Po Zakonu o usmerjanju otrok s posebnimi potrebami (2011) je v 2. členu opredeljeno, da so otroci s posebnimi potrebami: otroci z motnjami v duševnem razvoju, gluhi in naglušni otroci, slepi in slabovidni otroci oz. otroci z okvaro vidne funkcije, otroci z govorno-jezikovnimi motnjami, gibalno ovirani otroci, otroci s primanjkljaji na posameznih področjih učenja, otroci z avtističnimi motnjami, dolgotrajno bolni otroci in otroci s čustvenimi in vedenjskimi motnjami. Ti otroci potrebujejo prilagojeno izvajanje programov vzgoje in izobraževanja z dodatno strokovno pomočjo ali prilagojene programe vzgoje in izobraževanja oziroma posebne programe vzgoje in izobraževanja.

V osnovnih šolah je veliko otrok s posebnimi potrebami, ki ne gredo skozi postopek usmerjanja in ne dobijo formalnega statusa učenca s posebnimi potrebami (Opara, 2005). Iz 2. člena Zakona o usmerjanju otrok s posebnimi potrebami lahko vidimo, da v kategorizacijo otrok s posebnimi potrebami niso vključeni ne nadarjeni učenci ne učenci z učnimi težavami. Kljub temu Zakon o spremembah in dopolnitvah Zakona o osnovni šoli (2013) šoli nalaga, da otrokom z učnimi težavami prilagodi metode in oblike dela. To $\mathrm{v}$ praksi pomeni, da prepoznavanje in reševanje učnih težav temelji na petstopenjskem kontinuumu pomoči otroku z učnimi težavami, ki obsega pomoč učitelja pri pouku in dopolnilnem pouku, pomoč šolske svetovalne službe, dodatno individualno in skupinsko pomoč ter pomoč zunanje ustanove. Zadnja stopnja se pojavi, ko naštete oblike pomoči ne zadostujejo, zato se predlaga »odločba« oz. usmeritev v program s prilagojenim izvajanjem in dodatno strokovno pomočjo (Magajna, 2011). Magajna (prav tam) ob tem opozarja, da je celoten potek petih stopenj pomoči učinkovit le, če vsi strokovni delavci, starši in otroci dobro sodelujejo in uresničujejo svoje naloge, te pa je treba tudi evalvirati.

Otroci s posebnimi potrebami postajajo vse večji del populacije otrok v rednih osnovnih šolah. Po podatkih Ministrstva za izobraževanje, znanost in šport RS (2018) se je denimo v šolskem letu 2016/17 v rednih in prilagojenih osnovnošolskih programih izobraževalo 10.072 otrok s posebnimi potrebami, v šolskem letu 2017/18 pa 11.077 ali 6,18 \% vseh učencev v rednih osnovnošolskih programih. Za primerjavo z drugimi evropskimi državami: zadnji pridobljeni podatki za šolsko leto 2014/2015, ki jih je pridobila The European Agency for Special Needs and Inclusive Education (2016), prikazujejo, da je bilo v Sloveniji 7,79 \% otrok z odločbo za posebne izobraževalne potrebe, povprečje te raziskave, kjer je sodelovalo 30 evropskih držav, pa je 4,44 \%. Opara in drugi (2010) so kot enega izmed razlogov za povečanje števila otrok s posebnimi potrebami navedli »bonitete, ki izhajajo iz odločbe«. Odločbe namreč omogočajo pravico do koriščenja različnih oblik pomoči in podpor na področju vzgoje in izobraževanja (prilagojeno izvajanje programov, dodatna strokovna pomoč ipd.), starševskega varstva in družinskih prejemkov, zdravstva (medicinski pripomočki, povračila stroškov za zdravila ipd.) in davčnih olajšav (Murgel, 2014). 
V članku prikažem rezultate raziskave, ki sem jo izvedla, da bi predstavila položaj staršev, ko se odločijo za postopek usmerjanja skupaj z otrokom. Poudarek je na sodelovanju med starši otrok s posebnimi potrebami in socialnimi delavkami, ki opravljajo vlogo šolskih svetovalnih delavk, saj je vidik socialnega dela v osnovnih šolah izjemno pomemben.

\title{
Postopek usmerjanja otrok s posebnimi potrebami
}

Usmerjanje pomeni

\begin{abstract}
uradno prepoznavanje otroka s posebnimi potrebami v postopku usmerjanja in osnovo za uradni dokument - »odločba«, ki daje otroku pravico do prilagoditve in dodatne strokovne pomoči in pri zahtevnejših primerih vključitev v prilagojene programe, posebne programe oz. vzgojne programe. (Opara, 2015)
\end{abstract}

Raziskava, ki jo je izvedla Vovk Ornik (2016) v okviru doktorskega dela, je pokazala, da starši glede postopka usmerjanja pričakujejo, da bo odločba izboljšala učni uspeh otroka. V ozadju je njihova skrb, da bo otrok usmerjen v drug program, ki ga redne osnovne šole ne izvajajo, če kljub dodatni pomoči ne bo dosegal minimalnega standarda znanja.

V Sloveniji imamo sistem, $\mathrm{v}$ katerem o tem odloča komisija za usmerjanje otrok s posebnimi potrebami na podlagi strokovne presoje o otrokovem primanjkljaju. Komisija otroka usmeri v program vzgoje in izobraževanja in opredeli ustanovo, v katero se bo vključil. Starši se sicer lahko na odločitev komisije pritožijo. Natančen postopek usmerjanja otrok s posebnimi potrebami in nadaljnjo oblikovanje individualiziranega programa sem podrobneje opisala v svojem diplomskem delu (Plešec, 2019).

\section{Sodelovanje s starši otrok s posebnimi potrebami}

Najjasnejšo idejo o tem, kako poteka postopek usmerjanja v konkretnih primerih, nam lahko podajo prav starši otrok s posebnimi potrebami, vendar so pogosto spregledani. Strokovni delavci, ki sodelujejo z otrokom s posebnimi potrebami, so večinoma osredotočeni na otroka, manj pa na starše oz. na celotno družino, saj starše pogosto vidijo bolj kot spremljevalce otroka in posrednike informacij, čeprav se to ne bi smelo dogajati.

Starši pogosto poročajo, da niso razumeli izvidov, ki so jih prejeli od različnih strokovnjakov, da se ne znajdejo pri branju zakonodaje, poročil, individualiziranih programov in tudi ne v številnih pogovorih in sestankih.

(Jurišić, 2012, str. 90)

Izrazi, kot so »je usmerjen«, »ste oddali zahtevek«, »podpisali soglasje«, »je bil na komisiji«, in kratice (DSP, IP, OŠPP ipd.) so staršem tuji in pogosto nerazumljivi, trdi Jurišič (2012, str. 90), zato je toliko pomembneje, da strokovni delavec sproti preverja razumevanje staršev in jim približa jezik stroke, tako da jim prevede in pojasni strokovne izraze na njim razumljiv način.

$\mathrm{V}$ preteklosti so bili strokovnjaki nagnjeni k podcenjevanju znanja, ki ga imajo starši o svojih otrocih. Bili so prepričani, da so starši pri ocenjevanju 
otrokovih razvojnih dosežkov pristranski oziroma pretiravajo. Pogosto so bili izključeni iz postopkov ocenjevanja, s tem pa so si strokovnjaki zaščitili svojo avtoriteto in status (Dale, 1996). Menim, da je to tudi eden izmed vzrokov za to, da nekateri starši doživljajo občutke frustracij, manjvrednosti, ker jih učitelji raje nagovarjajo in jim dajejo navodila, namesto da bi jih poslušali.

Drabble (2013, str. 17) poudarja, da so številne študije potrdile obremenjenost staršev, ki vzgajajo otroka s posebnimi potrebami. Ti starši so pogosto poročali o občutkih izolacije in visoki ravni stresa, v nekaterih študijah je že kazalo na vedno večjo pojavnost depresije. Imeti otroka s posebnimi potrebami povzroča stres, ki je izziv za celotno družino, za starše, sorojence in druge sorodnike. Starševska odzivnost in občutljivost sta potrebni, da otroci s posebnimi potrebami razvijejo varno navezanost, zato je zagotavljanje podpore staršem otrok s posebnimi potrebami ključno za uspeh otroka in za družino kot celoto.

V prvih korakih je vsekakor treba razjasniti, kakšna so medsebojna pričakovanja in cilji staršev, učiteljev in strokovnih delavcev in kakšne so njihove prednosti pri različnih oblikah sodelovanja. Dejstvo je, da z vsemi starši ne bo mogoče razviti partnerskega odnosa; nekateri starši tega sploh ne želijo, drugi pa težko vzpostavijo odnos zaradi osebnostnih značilnosti ali narave svojega dela. Kljub temu pa obstaja večja verjetnost, da jih bomo pritegnili k sodelovanju, če jim bomo ponudili več raznovrstnih oblik sodelovanja in vključevanja (Kalin, 2009).

\section{Metodologija}

Ko sem v 3. letniku študija socialnega dela opravljala prakso v redni osnovni šoli, me je presenetilo število otrok s posebnimi potrebami. Pri delu s socialno delavko sem bila pozorna predvsem na težave, s katerimi se srečujejo starši otrok s posebnimi potrebami. Ko so oddajali zahtevo za usmeritev, se je zgodilo, da sploh niso povsem razumeli, kakšen je namen postopka, ki zadeva njihovega otroka. Ko so ugotovili, da bo njihov otrok dobil odločbo o usmeritvi in kaj to pravzaprav pomeni, so umaknili zahtevo in postopek se je ustavil, s tem pa je tudi učenec postal prikrajšan za določene prilagoditve v šoli, ki bi mu lahko koristile. Nerazumevanje postopka in premalo strokovne podpore povzročata različne odzive, velikokrat nesodelovanje s šolo. Pri tem pa se lahko spregleda, kaj je resnično najboljše za otroka. Zato sem se v raziskavi opirala na tri ključna raziskovalna vprašanja: ali obstaja razlika med pogledom šolskih socialnih delavk in staršev na postopek usmerjanja otrok s posebnimi potrebami? Kakšna je vloga šolskih socialnih delavk in staršev pri oblikovanju individualiziranega programa za otroka s posebnimi potrebami? Katera znanja imajo socialne delavke za delo z otroki s posebnimi potrebami v rednih osnovnih šolah?

\section{Vrsta raziskave, model raziskave in spremenljivke}

Raziskava je bila kvalitativna in eksplorativna (poizvedovalna), saj sem z besednimi opisi ali pripovedmi pridobila dober vpogled v njihovo doživljanje. Raziskava je tudi primerjalna, saj sem primerjala perspektivo staršev in socialnih delavk. 
Merski instrumenti ali viri podatkov

Merski instrument v raziskavi je delno strukturiran vprašalnik. Sestavljen je iz vprašanj, ki so odprtega tipa in postavljena tako, da so intervjuvanci odgovarjali s svojimi besedami in predstavili stvari, ki so zanje najpomembnejše. Vprašanja za starše otrok s posebnimi potrebami in socialne delavke so bila različno postavljena. Podatke sem dobila s pomočjo delno strukturiranih intervjujev s štirimi starši otrok s posebnimi potrebami, ki imajo svoje otroke vpisane v redno osnovno šolo, in s štirimi socialnimi delavkami, ki delajo na rednih osnovnih šolah v Ljubljani. Viri podatkov so pogovori s prej omenjeni osebami.

\section{Populacija in vzorčenje}

Populacijo raziskovalne naloge sestavljajo starši otrok s posebnimi potrebami, ki so vključeni v redne osnovne šole v Sloveniji in socialne delavke, ki so zaposlene na osnovnih šolah v Sloveniji. V vzorec sem zajela štiri starše otrok s posebnimi potrebami, ki obiskujejo redno osnovno šolo v ljubljanski regiji ter štiri socialne delavke, ki so zaposlene na ljubljanskih osnovnih šolah kot šolske svetovalne delavke. V raziskavi sem uporabila neslučajnostno vzorčenje, vzorec raziskovanja pa je priročni, saj sem se želela osredotočiti na starše otrok, ki so prejeli odločbo od komisije za usmerjanje otrok s posebnimi potrebami v zadnjih dveh letih (2018 in 2019). Izbiro za enoto populacije, ki so v mojem primeru starši, sem prepustila socialnim delavkam, ki jih bolj poznajo, izbira pa je bila odvisna tudi od pripravljenosti staršev na pogovor z mano.

\section{Zbiranje in analiza podatkov}

Intervjuje s starši in socialnimi delavkami sem izvajala v obdobju od 23. 1. 2019 do 22. 3. 2019. Najprej sem osebno stopila v stik s socialnimi delavkami in jim predstavila namen svoje raziskovalne naloge ter jih osebno povabila $\mathrm{k}$ sodelovanju za izvedbo intervjuja. Prav tako sem jih prosila, ali bi me lahko usmerile k staršem otrok s posebnimi potrebami, ki so v zadnjih dveh letih pridobili odločbo o usmeritvi. Ko sem dobila kontakte staršev, sem jih ustno nagovorila. Če so privolili v sodelovanje v raziskavi, smo se dogovorili za kraj in čas izvedbe pogovora. Pred izvedbo intervjuja sem staršem osebno pojasnila, kakšen je namen moje raziskave. S podpisom soglasja so bili seznanjeni, da bodo njihova osebna imena in imena otrok ostala anonimna. Vprašala sem jih, ali se strinjajo, da pogovore snemam. Če tega niso želeli, sem si njihove izjave sproti zapisala in takoj po končanem pogovoru zapise prepisala in začela analizo.

Zbrane podatke sem kvalitativno obdelala. Posnetke intervjujev oz. zapise sem najprej prepisala in vnesla $v$ računalnik. Intervjuje sem nato uredila in izločila podatke, ki niso relevantni za mojo raziskavo. Nato sem izjave označila s črko in številko. V fazi odprtega kodiranja sem zaradi lažje preglednosti izjave vnesla $v$ tabele in jim pripisala pojme. V zadnji fazi sem pojme združila v širše kategorije in podkategorije ter na podlagi tega zapisala rezultate. 


\section{Omejitve raziskave}

Omejitev raziskave sem zaznala v majhnem vzorcu, ki sem ga uporabila za empirični del raziskave. Razlog za majhen vzorec šolskih socialnih delavk bi pripisala majhnemu številu socialnih delavk, ki so zaposlene v ljubljanskih osnovnih šolah kot šolske svetovalne delavke, in pa slabšemu odzivu za sodelovanje $v$ raziskavi.

\section{Rezultati}

$\mathrm{V}$ raziskavi me je zanimalo mnenje staršev otrok s posebnimi potrebami. $\mathrm{Na}$ podlagi svojih izkušenj s strokovnim delavci v osnovnih šolah in drugih institucijah sem namreč ugotovila, da starši še vedno niso prepoznani kot ključni člen pri prepoznavanju otrokovih težav in nadaljnji obravnavi ter pomoči otroka. $V$ rezultatih sem primerjala poglede socialnih delavk in staršev otrok s posebnimi potrebami, s katerimi sem opravila pogovore.

\section{Sodelovanje šolske svetovalne službe in staršev}

Zgodnje odkrivanje otrokovih težav je prednost, ki jo poudarjajo socialne delavke. Socialne delavke sodelovanje s starši začnejo s pogovorom, v katerem starše informirajo o otrokovih težavah, še prej pa vzpostavijo sodelovanje tudi z otrokom. S starši medsebojno sodelujejo, skupaj oblikujejo instrumentalno definicijo, raziskujejo in soustvarjajo rešitve. Vse socialne delavke poudarjajo izvajanje predhodnih prilagoditev za otroka, ki vključuje pripravo izvirnega delovnega projekta pomoči oz. individualno skupinsko pomoč in soglasje staršev za osebno mapo otroka. Socialne delavke poudarjajo, da so pri starših opazni predsodki o odločbi in strah pred etiketiranjem otroka ob postopku usmerjanja. V enem primeru so zato, ker so starši zavračali postopek usmerjanja, vključili center za socialno delo. Socialne delavke opažajo, da imajo starši visoka pričakovanja glede otrokovega šolskega uspeha, ko otrok prejme odločbo, zato je pritisk pri nekaterih starših še večji, zato se med starši in šolskimi strokovnimi delavci pojavljajo nesoglasja.

Socialne delavke bi si od staršev želele zaupanja do šolske svetovalne službe in da bi se njihov medsebojni odnos med šolanjem otroka ohranjal in razvijal. Zavedajo se, da sta pri takšnem sodelovanju potrebni tankočutnost in empatija. Menijo, da bi morali vsi strokovni delavci izhajati iz perspektive moči in krepiti tudi druga področja otroka, ne zgolj tista s pomanjkljivostmi. Posvetovanje učitelja s šolsko svetovalno službo je bila ena izmed želenih sprememb, to pa kaže, da v praksi tega ne uporabljajo vsi.

Sodelovanje šolskih svetovalnih delavcev z otroki in starši poteka redno $\mathrm{v}$ obliki osebnih in telefonskih stikov, tudi po prejeti odločbi otroka. Če so starši imeli pogovore s šolsko svetovalno delavko v zvezi s postopkom usmerjanja za oba otroka, so opazili razliko, da je pri drugem otroku komunikacija s šolsko svetovalno delavko potekala jasneje in bolj neposredno - to je staršem pomagalo. 
Šolska svetovalna služba je v večini primerov prva, ki starše informira o samem postopku usmerjanja, zato me je zanimalo, s katerimi pravicami in možnostmi so bili seznanjeni, ko so njihovi otroci prejeli odločbe. V večini so bili starši najprej seznanjeni s številom ur dodatne strokovne pomoči. Pri pregledu odločbe je bila v dveh primerih v pomoč socialna delavka. Kljub seznanjenosti z otrokovimi pravicami in možnostmi s pridobljeno odločbo se niso vsi starši odločili za njihovo koriščenje. V preostalih dveh primerih starši niso bili seznanjeni s pravicami otroka s posebnimi potrebami. S prilagoditvami za pisno ocenjevanje so bili nekateri seznanjeni zgolj iz strokovnega mnenja. $\mathrm{V}$ drugem primeru pa sta starša prešolala svoje otroke zaradi nestrokovnega dela in na novi šoli opazila velike razlike med osnovnimi šolami.

\section{Pogled socialnih delavk in staršev na celoten postopek usmerjanja otrok $s$ posebnimi potrebami}

Analiza odgovorov je pokazala, da celoten postopek usmerjanja traja predolgo, prav tako je v postopku zelo veliko dokumentacije, ki celoten postopek le upočasni. Socialne delavke navajajo nepravilnosti, kot so nepopolne odločbe in napačni osebni podatki v odločbi. Socialne delavke navajajo, da starši vse več obiskujejo zasebnike, saj je svetovalni center zelo obremenjen, hkrati pa menijo, da je strokovnih obravnav premalo. Socialne delavke so sicer brez vpogleda v delovanje komisije, vendar na podlagi izkušenj pri svojem delu in pridobljenih informacij vedo, da komisija mnenje o otroku ustvari na podlagi poročil in da komisija ne razpolaga z informacijami o otrokovem napredku.

Pri oblikovanju individualiziranega programa poudarjajo vključevanje vseh udeleženih in medsebojno sodelovanje, a kljub temu otroke v načrtovanje takšnega programa nekatere šole vključujejo šele od 4. razreda. Strokovni delavci pri oblikovanju individualiziranega programa izhajajo iz strokovnega mnenja in odločbe, vendar je ena socialna delavka pojasnila, da je tak program pogosto narejen rutinsko, čeprav je dovolj možnosti za kreativno oblikovanje.

Polovica staršev meni, da postopek traja dolgo in da so čakalne vrste za začetek samega postopka in obravnavo otroka predolge. Druga polovica staršev pa je imela nasprotno izkušnjo in so poročali o hitrem poteku postopka usmerjanja.

Polovica staršev je aktivno sodelovala pri oblikovanju individualiziranega programa, druga polovica pa ni sodelovala ali pa se je s predlaganimi prilagoditvami samo strinjala. Polovica staršev svoje vloge v postopku usmerjanja ne vidi kot zelo pomembne, saj menijo, da niso dovolj usposobljeni, da bi imeli v takem postopku večjo vlogo. Staršem primanjkuje izobraževanj in svetovanj na šoli. Pogrešajo zgodnje informiranje, podporo, sodelovanje in jasno komunikacijo, ko pri otroku zaznajo težave.

Analiza odgovorov je pokazala drugačno opažanje otroka doma in v šoli. Pri večini so šola oziroma starši zgodaj odkrili otrokove težave. Starši poročajo o dobrem sodelovanju s socialno delavko, prek katere so pridobili informacije o odločbi, in so opustili predsodke o »nalepkah«, ki naj bi jih "prilepila« odločba. Po drugi strani pa so nekateri starši opazili zadržan pristop socialne 
delavke ob predaji informacij o postopku usmerjanja. Prav takšen pristop je povzročil nejasno komunikacijo in nerazumevanje staršev o pomenu testiranja v postopku usmerjanja.

\section{Razprava}

V nadaljevanju sem v razpravi vključila raziskovalni vprašanji, ki sem si ju postavila na začetku empiričnega raziskovanja.

1. Ali obstaja razlika med pogledom šolskih socialnih delavk in staršev na postopek usmerjanja otrok s posebnimi potrebami?

Sistem usmerjanja otrok s posebnimi potrebami v Sloveniji je ves čas deležen kritik na račun zapletenosti postopka usmerjanja, dolgotrajnosti postopka od oddaje vloge do izdelanega strokovnega mnenja in odločbe o usmeritvi, in na račun kakovosti strokovnih mnenj in (ne)vključevanja staršev in učiteljev v proces priprave strokovnega mnenja (Vovk Ornik, 2016).

Na vprašanji, zakaj celoten postopek usmerjanja traja tako dolgo in zakaj se pojavljajo tako velike časovne razlike med posameznimi primeri, bi verjetno znale bolje odgovoriti institucije, ki vodijo postopek usmerjanja. Glede na pridobljene rezultate, ki kažejo, da so izkušnje staršev take, da je težko najti strokovnjake za pridobitev strokovnega mnenja o otroku, bi bilo treba zagotoviti več strokovnih delavcev na področju ocenjevanja otrok za postopek usmerjanja, saj se tudi potrebe po odločbi za otroka s posebnimi potrebami povečujejo.

Skoraj odločilno vlogo v postopku usmerjanja imajo člani komisije za usmerjanje otrok s posebnimi potrebami, saj na koncu podajo svoje strokovno mnenje o potrebnih prilagoditvah otroka. Starši so imeli zelo različne izkušnje $\mathrm{s}$ komisijo. Z nekaterimi je komisija stik navezala le prek telefona, $\mathrm{v}$ dveh primerih so se dejansko sestali, pri nekaterih pa stika sploh ni bilo. Nekaterim je stik s komisijo smiseln in pomemben, drugim je bilo pomembneje, da se postopek usmerjanja izpelje do konca. V Navodilih o delu komisij za usmerjanje otrok s posebnimi potrebami na prvi stopnji (2015) je zapisano, da lahko člani komisije predlagajo dodatne storitve, med katerimi je tudi pogovor $\mathrm{z}$ otrokom oz. starši. Pogovor z otrokom oz. starši torej ni obvezna naloga, ki jo mora izvesti komisija za usmerjanje otrok s posebnimi potrebami, ampak bolj možnost, če komisija oceni, da je potreben pogovor.

Zaradi neusklajenosti strokovnega mnenja z dejanskim stanjem otroka, ki ga obravnavajo, menim, da bi bilo treba možnost pogovora s starši in otroki zakonsko spremeniti v obveznost komisije za usmerjanje otrok s posebnimi potrebami, saj poročila šole, zdravnikov in drugih strokovnjakov ne pokažejo vedno prave slike otroka. Pri tem izhajam iz izkušenj staršev, ki so se v postopku usmerjanja srečevali s strokovnimi delavci, ki so si iz poročil ustvarili mnenje o otroku, v resnici pa so ga starši v domačem okolju videli povsem drugače in so morali zagovarjati svoj pogled. Starši so pomemben vir informacij, ki jih je treba vključevati v sam proces obravnave. Menim, da bi bilo treba pri sodelovanju z otrokom izhajati iz tega, da na otroka gledamo celostno, ne zgolj na njegovo delovanje v razredu. 
Še večjo pozornost potrebuje področje sodelovanje s starši, saj je postopek usmerjanja otrok s posebnimi potrebami skoraj v celoti odvisen od zakonske ureditve. Od pristopa in načina sodelovanja strokovnih delavcev je odvisno, ali bodo starši v odnosu do njih vzpostavili zaupanje in se skupaj odločili za postopek usmerjanja, kjer se kaže potreba po tem.

Če hočemo v naših šolah uveljaviti sodoben koncept dela s starši, moramo starše dojemati kot partnerje. Ne kot partnerje v pomenu strokovnega znanja, temveč kot partnerje v delovanju za skupni cilj (Ljubešić, 2012, str. 39). Knafelc (2014, str. 84) meni, da bi morali starši, učitelji in strokovni delavci predvsem z vidika skrbi za otroka graditi partnerski odnos, saj je njihova skupna vez in skupni interes posameznik, ki ga spremljajo starši doma in strokovni delavci v šoli.

$\mathrm{V}$ intervjujih s socialnimi delavkami in starši sem lahko slišala primere, $\mathrm{v}$ katerih je bilo sodelovanje s starši oteženo, saj so imeli do postopka usmerjanja določene zadržke. Nekateri starši se bojijo, da bo odločba otroka zaznamovala $\mathrm{z}$ etiketo in da ga bodo vrstniki in širša družba zato manj cenili. Ob tem moram omeniti, da sta v Sloveniji postopek usmerjanja in sama odločba še vedno tabu temi. Pomembno se mi zdi, da strokovnjaki, ki sestavljajo strokovne time in testirajo otroke, znajo staršem pojasniti postopek in jim ponuditi vse pomembne informacije. Kljub temu pa je prvi ključni korak odvisen od šole. Pomembno je, kako pristopi do staršev, ko se začnejo pogovarjati o postopku usmerjanja. Izkušnja matere, ki ni vedela, kako naj bi bilo testiranje otroka videti, je primer nejasne komunikacije, saj socialna delavka pri sogovornici ni preverila razumevanja. Kot mama, ki se s takšno situacijo in s postopkom usmerjanja še ni srečala, seveda ni vedela, kako naj bi bilo testiranje videti. Če starši dobijo vse informacije in se lahko odkrito pogovarjajo s strokovnimi delavci v šoli o svojih pogledih ali dvomih, je to korak v pravo smer.

2. Kakšna je vloga šolskih socialnih delavk in staršev pri oblikovanju individualiziranega programa za otroka s posebnimi potrebami?

$\mathrm{Z}$ drugim raziskovalnim vprašanjem se osredotočam na individualiziran program. Ena od najpomembnejših pravic otroka s posebnimi potrebami je gotovo prav individualiziran program. Starši lahko sodelujejo pri pripravi takšnega programa za otroka, in sicer lahko med drugim predlagajo cilje za svojega otroka. Ni nujno, da se ti cilji nanašajo zgolj na učne cilje. To so lahko tudi cilji na področju prilagojenega vedenja, samostojnosti, učnih strategij, komunikacije in podobno. Starši naj spremljajo otrokov napredek med šolskim letom, saj to omogoča šolskim strokovnim delavcem, da se bo otrok učil tisto, kar zmore, in v skladu s tem je treba prilagoditi časovno razporeditev učne snovi pri pouku (Jurišić, 2010, str. 55).

V pogovorih s starši sem zaznala aktivno sodelovanje pri oblikovanju individualiziranega programa samo $v$ dveh primerih, v katerih so starši skupaj s strokovno skupino iskali najboljše možnosti za otroka. Bolj kot to pa me je presenetil pogled staršev o svoji vlogi v postopku usmerjanja in oblikovanja individualiziranega programa, saj menijo, da so starši laiki v teh procesih, in ker niso usposobljeni za to, se raje ne vmešavajo. Mogoče je takšno razmišljanje enega izmed staršev tudi posledica slabega sodelovanja s prejšnjo šolo, vendar mislim, da bi se starši morali zavedati, kako zelo pomemben člen so 
v procesih, v katerih je v središču njihov otrok. Da starši pridobijo občutek pomembnosti in vrednosti, je naloga šolske svetovalne službe. Najti mora najboljši možni način, da jih vključuje v pogovore, ubesedi njihov pomemben prispevek pri raziskovanju in soustvarjanju sprememb in želenih izidov.

Čačinovič Vogrinčič (2011, str. 7) poudarja, da se v pogovoru pridobi za socialno delo tako pomembna izkušnja spoštovanja in osebnega dostojanstva. Starši in otroci so v strokovni skupini člani, ki pogosto ne poznajo vseh možnosti in pravic v postopku ter pri načrtovanju individualiziranega programa, zato so strokovni delavci, ki sodelujejo z njimi, so-delavci in so-ustvarjalci v skupnem projektu in je od njih odvisno, da jim takšen program bolje pojasnijo. Stroka je torej pri načrtovanju individualiziranega programa zelo pomembna, vendar je treba paziti, da strokovni delavci ne izhajajo iz pozicije moči, saj lahko mnenje stroke prevlada nad mnenjem staršev. Če hočemo, da bo individualiziran program oblikovan tako, da bo otroku v pomoč, je prav, da se starše in otroke obravnava kot enakovredne člane strokovne skupine in se jim omogoči prostor za interpretacijo in lasten prispevek.

Zakon o usmerjanju otrok s posebnimi potrebami (2011) določa, da mora biti otrok vključen v pripravo in spremljanje individualiziranega programa, pri tem pa je treba upoštevati njegovo zrelost in starost. Tu pa se pojavljajo pomisleki, kdaj je po mnenju odraslih določen otrok primerno zrel in star, da lahko sodeluje v zadevah, ki zadevajo prav njega. Dve socialni delavki sta povedali, da otroke $v$ načrtovanje individualiziranega programa vključujejo od 4. razreda. Lansdown (2010, str. 15) opozarja, da so otroci velikokrat spregledani in preslišani, ker odrasli podcenjujejo njihove sposobnosti, ali pa njihovo mnenje ni izraženo tako, kot bi si želeli odrasli. Zato je lažje reči, da se bo otroka vključevalo v načrtovanje, ko bo kaj »znal ubesediti«. 0 tem piše Kodele (2017, str. 21), ko na podlagi Konvencije o otrokovih pravicah (1989) problematizira pomen zrelosti in starosti otroka. Opozarja na realnost, da otrok lahko izrazi svoje mnenje, vendar so odrasli tisti, ki na koncu presodijo, ali je otrok dovolj star, da bi se njegovo mnenje upoštevalo. Otroci se razvijajo zelo različno, njihova raven razumevanja je odvisna tudi od okolja, v katerem živijo, izkušenj, podpore staršev ipd., zato se mi zdi, da določanje meje, od katerega razreda jih bomo aktivno vključevali v pripravo individualiziranega programa, ni najboljši način participacije otroka. Če otrok razume problem in situacijo, o kateri potekajo pogovori, je pomembno upoštevati njegovo zrelost, ne pa njegovo starost. Navsezadnje je otrokova aktivna vloga pri načrtovanja individualiziranega programa pomembna, ker je otrok sam »strokovnjak na podlagi svojih osebnih izkušenj«.

\section{Sklep}

V sodelovanju šolske svetovalne službe s starši se mi zdita ključni informiranje in povečevanje moči staršev. Kot sem spoznala na podlagi pogovorov, sta v slovenskem prostoru postopek usmerjanja in odločba še vedno tabu temi. Ko bi morali starši podpreti otroka v postopku usmerjanja, jih zaradi pomanjkanja informacij in strahu, kaj vse jih čaka, preplavi občutek nemoči. Pri tem 
je pomembno, da šolska svetovalna služba staršem zagotovi vse pomembne informacije in jih opozori na njihove pravice in dolžnosti v postopku usmerjanja otroka s posebnimi potrebami, tako da niso prisiljeni sami iskati vseh dodatnih informacij.

Prav tako nekateri starši potrebujejo konkretne usmeritve, kako organizirati otrokovo učenje in šolsko delo $\mathrm{v}$ domačem okolju. Ena izmed oblik pomoči staršem so podporne skupine. V njih imajo starši otrok s posebnimi potrebami možnost v varnem in sprejemajočem okolju prositi za pomoč, če imajo občutek, da je drugje niso dobili dovolj. To je prostor za zaupanje izkušenj in informacij o otrokovih težavah, poleg tega pa lahko spoznajo, kako se z različnimi ovirami spoprijemajo drugi starši. Starši tako ustvarjajo svojo podporno mrežo, si povečajo moč in hkrati lažje pomagajo otroku.

Za organizacijo takšnih podpornih skupin bi spodbudila študente magistrskih programov socialnega dela, psihoterapije in specialne pedagogike, saj bi tako starši dobili občutek, da so njihove potrebe bolj upoštevane. Sebi pa bi z vodenjem podporne skupine za starše otrok s posebnimi potrebami omogočili nabiranje novih izkušenj za delo z ljudmi. S svojim znanjem lahko prispevamo veliko.

\section{Viri}

Čačinovič Vogrinčič, G. (2011). Soustvarjanje v delovnem odnosu: izvirni delovni projekt pomoči. V L. Šugman Bohinc (ur.), Učenci z učnimi težavami: izvirni delovni projekt pomoči. Ljubljana: Fakulteta za socialno delo.

Dale, N. (1996). Working with families of children with special needs: partnership and practice. London: Routledge.

Drabble, S. (2013). Support for children with special educational needs (SEN). European Union: RAND Europe. Pridobljeno 3. 1. $2019 \mathrm{~s} \mathrm{https://www.rand.org/content/dam/rand/}$ pubs/research_reports/RR100/RR180/RAND_RR180.pdf

Jurišić, B. D. (2010). Sodelovanje staršev pri usmerjanju in šolanju otrok z motnjo v duševnem razvoju. V B. D. Jurišić, \& A. Šečih (ur.), 3. posvet na temo: življenje oseb z Downovim sindromom - usmerjanje otrok z Downovim sindromom in drugih otrok z motnjo v duševnem razvoju (str. 42-59). Ljubljana: Sožitje, Sekcija za Downov sindrom.

Jurišić, B. D. (2012). Blokade v komunikaciji s starši in tehnike poslušanja. V B. D. Jurišić (ur.), 5. strokovno srečanje na temo: življenje oseb z Downovim sindromom - komunikacija med starši in strokovnjaki (str. 81-93). Ljubljana: Sožitje, Sekcija za Downov sindrom.

Kalin, J. (2009). Pedagoški vidiki sodelovanja učiteljev in staršev - izzivi za učitelje, šolo, starše in družbeno skupnost. V F. Cankar, \& T. Deutsch, (ur.), Šola kot stičišče partnerjev: sodelovanje šole, družine in lokalnega okolja pri vzgoji in izobraževanju otrok (str. 83-99). Ljubljana: Zavod RS za šolstvo.

Knafelc, B. (2014). Vključevanje deležnikov in uporaba sodobnih pristopov pri izvajanju kakovostnega vzgojno-izobraževalnega procesa. Šolsko svetovalno delo: revija za svetovalne delavce $v$ vrtcih, šolah in domovih, 18(1/2), 81-91. Ljubljana: Zavod RS za šolstvo.

Kodele, T. (2017). Participacija učencev v procesu reševanja njihovih učnih težav (Doktorsko delo). Pridobljeno 27. 3. 2019 s http://pefprints.pef.uni-lj.si/4890/1/doktorska_disertacija_Kodele.pdf

Konvencija o otrokovih pravicah (1998). Pridobljeno 3. 12. $2021 \mathrm{~s}$ https://www.gov.si/assets/ ministrstva/MZZ/Dokumenti/multilaterala/clovekove-pravice/porocila-SLO-po-instrumentih-o-clovekovih-pravicah/73241a9c65/Konvencija-o-otrokovih-pravicah.pdf 
Lansdown, G. (2010). The realisation of children`s participation rights: critical reflections. V B. Percy-Smith, \& N. Thomas (ur.), A handbook of children and young people's participation: perspectives from theory and practice (str. 11-23). Pridobljeno 27. 3. $2019 \mathrm{~s}$ https://books.google.si/books?id=WOePAgAAQBAJ\&dq=A+Handbook+of+Children+an$\mathrm{d}+$ Young +People\%27s+Participation:+Perspectives+from +...chl=sl

Ljubešić, M. (2012). Sporočanje razvojnih dosežkov in drugi kočljivi pogovori. V B. D. Jurišić (ur.), 5. strokovno srečanje na temo: življenje oseb z Downovim sindromom - komunikacija med starši in strokovnjaki (str. 15-26). Ljubljana: Sožitje, Sekcija za Downov sindrom.

Magajna, L. (2011). Prepoznavanje in diagnostično ocenjevanje specifičnih učnih težav pri učenju: problemi in modeli. V L. Magajna, \& M. Velikonja (ur.), Učenci z učnimi težavami. Ljubljana: Pedagoška fakulteta Univerze v Ljubljani.

Ministrstvo za izobraževanje, znanost in šport RS (2018). Podatki v zvezi z učenci s posebnimi potrebami v osnovnih šolah s prilagojenim izvajanjem in dodatno strokovno pomočjo. Pridobljeno 20. 11. $2018 \mathrm{~s} \mathrm{http://www.mizs.gov.si/fileadmin/mizs.gov.si/pageuploads/}$ podrocje/posebne_potrebe/pdf/Tabela_ucenci_s_posebnimi_potrebami.pdf

Murgel, J. (2014). Vodnik po pravicah otrok s posebnimi potrebami. Ljubljana: IUS Software, GV Založba.

Navodila o delu komisij za usmerjanje otrok s posebnimi potrebami na prvi stopnji (2015). Zavod RS za šolstvo. Pridobljeno 3. 4. 2019 s https://www.zrss.si/zrss/wp-content/uploads/ navodila-o-delu-komisij-za-uopp-na-prvi-stopnji-11112015.pdf

Opara, B. (2005). Otroci s posebnimi potrebami v vrtcih in šolah: vloga in naloga vrtcev in šol pri vzgoji in izobraževanju otrok s posebnimi potrebami. Ljubljana: Centerkontura.

Opara, B. (2015). Dodatna strokovna pomoč in prilagoditve pri vzgoji in izobraževanju otrok s posebnimi potrebami. Ljubljana: Centerkortuna.

Opara, B., Barle Lakota A., Globačnik, B., Kobal Grum, D., Košir, S., Macedoni Lukšič, M., idr. (2010). Analiza vzgoje in izobraževanja otrok s posebnimi potrebami v Sloveniji. Ljubljana: JRZ Pedagoški Inštitut. Pridobljeno 16. 12. 2018 s https://www.gov.si/teme/usmerjanje-otrok-s-posebnimi-potrebami/

Plešec, N. (2019). Strokovna podpora staršem v postopku usmerjanja otrok s posebnimi potrebami (Diplomsko delo). Ljubljana: Fakulteta za socialno delo.

The European Agency for Special Needs and Inclusive Education (2016). European Agency statistics on inclusive education: 2016 dataset cross-country report. Odense, Denmark. Pridobljeno 12. 2. 2019 s https://www.european-agency.org/data/key-messages-findings

Vovk Ornik, N. (2016). Vloga učitelja v procesu usmerjanja otrok s posebnimi potrebami (Doktorsko delo). Pridobljeno z Repozitorij Univerze v Ljubljani. Pridobljeno 16. 12. $2018 \mathrm{~s}$ http://pefprints.pef.uni-lj.si/3708/

Zakon o spremembah in dopolnitvah Zakona o osnovni šoli (2013). Ur. l. RS, št. 63/13.

Zakon o usmerjanju otrok s posebnimi potrebami (2011). Ur. l. RS, št. 54. 